\title{
A rapid low-cost real-time PCR for the detection of klebsiella pneumonia carbapenemase genes
}

\author{
Lijun Wang, Haitong Gu and Xinxin Lu*
}

\begin{abstract}
Background: Klebsiella pneumonia carbapenemases (KPCs) are able to hydrolyze the carbapenems, which cause many bacteria resistance to multiple classes of antibiotics, so the rapid dissemination of KPCs is worrisome. Laboratory identification of KPCs-harboring clinical isolates would be a key to limit the spread of the bacteria. This study would evaluate a rapid low-cost real-time PCR assay to detect KPCs.

Methods: Real-time PCR assay based on SYBR Greenlwas designed to amplify a 106 bp product of the bla KPC gene from the159 clinical Gram-negative isolates resistant to several classes of $\beta$-lactam antibiotics through antimicrobial susceptibility testing. We confirmed the results of real-time PCR assay by the conventional PCR-sequencing. At the same time, KPCs of these clinical isolates were detected by the modified Hodge test (MHT). Then we compared the results of real-time PCR assay with those of MHT from the sensitivity and specificity. Moreover, we evaluated the sensitivity of the real-time PCR assay.

Results: The sensitivity and specificity of the results of the real-time PCR assay compared with those of MHT was 29/29(100\%) and 130/130(100\%), respectively. The results of the real-time PCR and the MHT were strongly consistent (Exact Sig. (2-tailed) =1. 000; McNemar test). The real-time PCR detection limit was about 0.8 cfu using clinical isolates.
\end{abstract}

Conclusion: The real-time PCR assay could rapidly and accurately detect KPCs -harboring strains with high analytical sensitivity and specificity.

Keywords: Real-time polymerase chain reaction, Klebsiella pneumonia carbapenemase

\section{Background}

Carbapenems are widely used to treat serious infections caused by multi-resistant Gram-negative bacteria. However, beginning with the initial description of a novel KPC from an isolate of K. pneumoniae in 2001 [1], carbapenem resistance in Enterobacteriaceae has been rapidly increasing. KPCs are able to hydrolyze the carbapenems, and cause resistance to multiple classes of antibiotics. Treatment of KPC-producing bacterial infection is thus a considerable challenge for clinicians. KPCs have been reported worldwide, such as North America, South America, Greece, Israel, Puerto Rico, China and so on [2-6]. The expanding geographic spread of KPCs underscores the importance of clinical recognition of these enzymes. In addition, KPCs have been found in

\footnotetext{
* Correspondence: trhospaper@gmail.com

Department of Laboratory Medicine, Beijing Tongren Hospital, Capital

Medical University, No1. Dongjiaominxiang Road, Dongcheng District, Beijing 100730, China
}

(c) 2012 Wang et al.; licensee BioMed Central Ltd. This is an Open Access article distributed under the terms of the Creative Commons Attribution License (http://creativecommons.org/licenses/by/2.0), which permits unrestricted use, distribution, and reproduction in any medium, provided the original work is properly cited. [7,8], P. mirabilis [9], Acinetobacter spp [6], P. aeruginosa , C. freundii [10], S. marcescens and E. coli [11]. This rapid dissemination of KPC is worrisome. Laboratory identification of KPC-harboring clinical isolates will be critical for limiting the spread.

However, detection of KPC -harboring stains in the clinical laboratory remained a difficult task. The failure of automated susceptibility testing systems to detect KPC-mediated carbapenems resistance was previously reported [12-14]. In 2009, the Clinical Laboratory Standards Institute (CLSI) guidelines (M100) recommended MHT to detect carbapenemase production. Wang et al. [15] noted that false positive results could occur when the MHT was used to detect carbapenemase in ESBLproducing isolates. MHT is time-consuming and not routinely tested for $E$. cloacae, $P$. aeruginosa in laboratory, so that many molecular detection of $b l a_{\mathrm{KPC}}$ genes were evaluated [16-19]. Rapid and sensitive $b l a_{\mathrm{KPC}}$ assays 
are critical to control the spread of $b l a_{\mathrm{KPC}}$-harboring bacteria in hospitalized patients.

In this paper, we would describe the development of a low-cost real-time PCR assay to screen clinical isolates for bla $\mathrm{KPC}$.

\section{Materials and methods Bacterial strains}

The following reference bacterial strains were the negative controls of bla $a_{\mathrm{KPC}}$ K. pneumoniaeATCC13883, extendedspectrum-b-lactamase-positive $K$. pneumoniaeATCC 700603, A. baumaniiATCC 19606, P. aeruginasaATCC 27853, C. albicansATCC 90029, E. coliATCC25922, E. faeciumATCC 35667 and methicillin-resistant S. aureusATCC 43300.

The 159 clinical isolates including K. pneumoniae, E. coli, E. cloacae, K. oxytoca, S. marcescens, P. mirabilis, MDR A.baumanii and MDR P. aeruginasa. were recovered from multiple infection sites like blood, wound, sputum, catheter, urine and pleural effusion from Beijing Tongren Hospital. These clinical isolates were resistant to several classes of $\beta$-lactam antibiotics, which were identified by antimicrobial susceptibility testing.

\section{Antimicrobial susceptibility testing}

Antimicrobial susceptibility testing was performed with the Vitek 2 susceptibility card AST-GN13 by Vitek 2 automated system (BioMérieux Inc, Durham, NC) according to the manufacturer's instructions. Minimum inhibitory concentration (MIC) results of imipenem and ertapenem were classified as susceptible, intermediate, or resistant based on the 2010 CLSI breakpoints (susceptible, $\leq 1 \mu \mathrm{g} / \mathrm{ml}$ and $\leq 0.25 \mu \mathrm{g} / \mathrm{ml}$; intermediate, $2 \mu \mathrm{g} / \mathrm{ml}$ and $0.5 \mu \mathrm{g} / \mathrm{ml}$; resistant, $\geq 4 \mu \mathrm{g} / \mathrm{ml}$ and $\geq 1 \mu \mathrm{g} / \mathrm{ml}$, respectively). However, the AST-GN13 card cannot classify organisms as susceptible to ertapenem without the dilutions less than $0.5 \mu \mathrm{g} / \mathrm{ml}$. All clinical isolates were subsequently tested by MHT. The indicator strains in MHT were E. coli ATCC 25922 for Enterobacteriaceae and K.pneumoniae ATCC 700603 for non- Enterobacteriaceae like P.aeruginosa [20].

\section{DNA isolation}

Bacterial strains were grown on MacConkey agar and incubated overnight at $35^{\circ} \mathrm{C}$. One colony was resuspended in $100 \mu \mathrm{l}$ of sterile distilled water and the cells were lysed by heating at $100^{\circ} \mathrm{C}$ for $10 \mathrm{~min}$. Cellular debris was removed by centrifugation at $13000 \mathrm{~g}$ for $10 \mathrm{~min}$, and the supernatant was used as a source of template DNA for amplification.

For analytical sensitivity based on bacterial colonyforming unit (cfu), DNA isolation was performed using the DNeasy Blood\&Tissue Kit (Qiagen Sciences, Maryland, USA) according to the protocol suggested by the manufacture. In brief, a bacterial suspension equivalent to that of a $2.0 \mathrm{McF}$ arland standard was prepared in saline, then $200 \mu \mathrm{l}\left(8.0 \times 10^{7} \mathrm{cfu}\right)$ suspension were serially diluted 10 -fold in saline. Bacterial total nucleic acid was extracted from $200 \mu \mathrm{l}$ of each dilution and then eluted in $50 \mu \mathrm{l}$ elution buffer and stored at $-20^{\circ} \mathrm{C}$.

\section{bla $a_{\mathrm{KPC}}$ detection by PCR -sequencing}

The presence of $b l a_{\mathrm{KPC}}$ was confirmed by conventional PCR and sequencing [1]. The primers included the forward (5'-TGTCACTGTATCGCCGTC-3') and the reverse (5'- CTCAGTGCTCTACAGAAAACC-3'), The PCR reaction system contained $0.5 \mu \mathrm{M}$ each primer, $2 \times$ EasyTaq PCR SuperMix (TransGen Biotech, Beijing, China) and $2 \mu \mathrm{l}$ DNA template. The reactions were amplified in a My Cycler thermal cycler (BIO-RAD, USA). Cycling parameters were $5 \mathrm{~min}$ at $95^{\circ} \mathrm{C}$, followed by 35 cycles of $1 \mathrm{~min}$ at $95^{\circ} \mathrm{C}, 30 \mathrm{~s}$ at $58^{\circ} \mathrm{C}$, and $1 \mathrm{~min} 30 \mathrm{~s}$ at $72^{\circ} \mathrm{C}$. The PCR amplification was ended by a final extension at $72^{\circ} \mathrm{C}$ for $10 \mathrm{~min}$. sequencing of the PCR products was commercially performed by SinoGenoMax Co. Ltd (Beijing, China). For sequence analysis, the BLAST program from the National Center for Biotechnology Information Web site was used (http: //www. ncbi. nlm. nih.gov/BLAST).

\section{bla $a_{\mathrm{KPC}}$ detection by real-time PCR}

The forward primer sequence (5'-TTGTTGATTGGC TAAAGGG-3') and reverse primer sequence (5'- CCATACACTCCGCAGGTT-3') were designed in the conservative region of several $b l a_{\mathrm{KPC}}$ types $\left(b l a_{\mathrm{KPC}-2}\right.$ to $\left.b l a_{\mathrm{KPC}-13}\right)$. The bla $a_{\mathrm{KPC}}$ amplicon was 106 base pairs (GenBank: EU244644).

The $25 \mu \mathrm{l}$ real-time PCR mixture contained 12. $5 \mu \mathrm{l}$ TransStart Green qPCR super MIX (TransGen Biotech, Beijing, China), $0.5 \mu \mathrm{l}$ PCR enhancer (TransGen Biotech, Beijing, China), $0.2 \mu \mathrm{M}$ each primer, $9 \mu \mathrm{l}$ sterile distilled water and $2 \mu \mathrm{l}$ DNA template. Real-time PCR amplification was performed using the Roche Light cycler 480 Realtime system (Roche Diagnostics, Mannheim, Germany). Cycling parameters were $5 \mathrm{~min}$ at $95^{\circ} \mathrm{C}$, followed by 40 cycles of $15 \mathrm{~s}$ at $95^{\circ} \mathrm{C}, 15 \mathrm{~s}$ at $55^{\circ} \mathrm{C}$, and $30 \mathrm{~s}$ at $72^{\circ} \mathrm{C}$. Single fluorescence detection was performed in each cycle at $55^{\circ}$ C. Melting curve acquisitions were done immediately after the final amplification step by heating at $96^{\circ} \mathrm{C}$ for $5 \mathrm{~s}$, cooling to $55^{\circ} \mathrm{C}$ for $1 \mathrm{~min}$, and heating slowly at $0.11^{\circ} \mathrm{C}$ per second to $96^{\circ} \mathrm{C}$ with continuous fluorescence recording. Melting curves were recorded by plotting fluorescence signal intensity versus temperature. Amplicon melting temperatures(Tm) were determined by calculating the derivative of the curve using Roche Light cycler 480 software. The results were visualized by plotting the negative derivative against temperature.

\section{Specificity and sensitivity}

In order to determine analytical sensitivity of our assay, bla $a_{\mathrm{KPC}}$ real-time PCR experiments were performed on 10- 
fold serial dilutions of bacterial cultures $\left(8.0 \times 10^{7} \mathrm{cfu}\right)$. To evaluate the analytical specificity, a panel of reference stains and clinical strains resistant to several classes of $\beta$ lactam antibiotics was tested. For statistical analysis, we used the MHT as the reference standard. The differences between sensitivities of the real-time PCR assay and MHT were evaluated with the McNemar test.

\section{Results}

The specificities of the real-time PCR primers for the detection of $b l a_{\mathrm{KPC}}$ genes were evaluated by the BLAST search program, available at www.ncbi.nlm.nih.gov.

The bla $a_{\mathrm{KPC}}$ real-time PCR assay was negative with DNA extracted from the following reference bacterial isolates: K.pneumoniae ATCC 13883, extended-spectrumb-lactamase-positive K.pneumoniae ATCC 700603, A. baumanii ATCC 19606, P. aeruginasa ATCC 27853, C. albicans ATCC 90029, E. coli. ATCC25922, E. faeciumATCC 35667 and methicillin-resistant S. aureusATCC 43300.

159 clinical isolates were categorized according to the susceptibility of imipenem or ertapenem (Table 1). 53 isolates were intermediate to resistant to imipenem or ertapenem, and 106 isolates were susceptible to carbapenems. 29 clinical isolates with carbapenem resistance or decreased susceptibility were positive by MHT and by real-time PCR and sequencing, respectively. The 29 clinical isolates included $20 \mathrm{~K}$. pneumoniae (MICs: imipenem $\geq 16 \mu \mathrm{g} / \mathrm{ml}$, ertapenem $\geq 8 \mu \mathrm{g} / \mathrm{ml}$ ), 3 E. coli (one strain MICs: imipenem $\leq 1 \mu \mathrm{g} / \mathrm{ml}$, ertapenem $=2 \mu \mathrm{g} / \mathrm{ml}$; two strains MICs: imipenem $\geq 16 \mu \mathrm{g} / \mathrm{ml}$, ertapenem $\geq 8 \mu \mathrm{g} / \mathrm{ml}$ ), 4 E. cloacae (MICs: imipenem $\geq 16 \mu \mathrm{g} / \mathrm{ml}$, ertapenem $\geq 8 \mu \mathrm{g} / \mathrm{ml}$ ), one $S$. marcescens (MICs: imipenem $\geq 16 \mu \mathrm{g} / \mathrm{ml}$, ertapenem $\geq 8$ $\mu \mathrm{g} / \mathrm{ml}$ ), and one MDR A. baumanii (MICs: imipenem $\geq 16$ $\mu \mathrm{g} / \mathrm{ml}$, ertapenem $\geq 8 \mu \mathrm{g} / \mathrm{ml})$. One carbapenem-resistant

Table 1 Results of Carbapenem susceptibility and MHT of clinical isolates

\begin{tabular}{|c|c|c|c|c|c|}
\hline \multirow[t]{2}{*}{ Species } & \multirow[t]{2}{*}{$\begin{array}{l}\text { No. of } \\
\text { isolates }\end{array}$} & \multicolumn{2}{|c|}{$\begin{array}{l}\text { No. of Carbapenem } \\
\text { susceptibility }\end{array}$} & \multicolumn{2}{|c|}{ No. of $\mathrm{MHT}^{*}$} \\
\hline & & $\begin{array}{l}\text { Intermediate } \\
\text { to resistant }\end{array}$ & Susceptible & Positive & Negative \\
\hline K. pneumoniae & 53 & 22 & 31 & 20 & 33 \\
\hline E. coli & 45 & 4 & 41 & 3 & 42 \\
\hline E. cloacae & 19 & 4 & 15 & 4 & 15 \\
\hline K. oxytoca & 10 & 0 & 10 & 0 & 10 \\
\hline P. mirabilis & 8 & 0 & 8 & 0 & 8 \\
\hline S. marcescens & 2 & 1 & 1 & 1 & 1 \\
\hline $\begin{array}{l}\text { MDR A. } \\
\text { baumanii }\end{array}$ & 11 & 11 & 0 & 1 & 10 \\
\hline $\begin{array}{l}\text { MDR } P \text {. } \\
\text { aeruginasa }\end{array}$ & 11 & 11 & 0 & 0 & 11 \\
\hline
\end{tabular}

*: MHT modified Hodge test. isolate of $K$. pneumoniae (MICs: imipenem $\geq 16 \mu \mathrm{g} / \mathrm{ml}$, ertapenem $\geq 8 \mu \mathrm{g} / \mathrm{ml}$ ) recovered from sputum was MHT $(-) / b l a_{\mathrm{KPC}}(-)$ in our assay. In addition, both isolate of $K$. pneumonia (MICs: imipenem $\leq 1 \mu \mathrm{g} / \mathrm{ml}$, ertapenem $\geq 8 \mu \mathrm{g} / \mathrm{ml}$ ) and E. coli (MICs: imipenem $\leq 1 \mu \mathrm{g} / \mathrm{ml}$, ertapenem $=2 \mu \mathrm{g} / \mathrm{ml})$ were MHT $(-) / b l a_{\mathrm{KPC}}(-)$, which were recovered from catheter. All 130 isolates (33 K. pneumoniae, 42 E. coli, 15 E. cloacae, $10 \mathrm{~K}$. oxytoca, one S. marcescens, 8 P. mirabilis, 10 MDR A. baumanii and 11 MDR P. aeruginasa) were MHT ( - )/ $\operatorname{bla}_{\mathrm{KPC}}(-)$ (Table 2). The sensitivity of the real-time PCR assay as compared to the MHT was 29/29(100 \%) with a specificity of $130 / 130(100 \%)$. The results of the real-time PCR and the MHT were strongly consistent (Exact Sig. (2-tailed) =1.000; McNemar test).

All bla $a_{\mathrm{KPC}}$ genes of KPC-producing isolates in this study were verified as $b l a_{\mathrm{KPC}-2}$ by sequencing assay.

The $b l a_{\mathrm{KPC}}$ amplicon was distinguished by its specific $\mathrm{Tm}$ value. Under our experimental conditions, analysis of the melting curve profile of the PCR products indicated that the products peaked at about $89^{\circ} \mathrm{C}$ (Figure 1).

The analytical sensitivity of the $b l a_{\mathrm{KPC}}$ real-time PCR assay was determined after serially diluting known concentrations $\left(8.0 \times 10^{7} \mathrm{cfu}\right)$ of clinical isolated carbapenemsresisant $K$. pneumoniae. The dynamic range of the assay covered nine orders of magnitude from $8.0 \times 10^{7}$ to $0.8 \mathrm{cfu}$. $b l a_{\mathrm{KPC}}$ specific fluorescent peaks were detected in the isolates dilutions to about $0.8 \mathrm{cfu}$ (Figure 2).

\section{Discussion}

Along with the wide use of carbapenem antibiotics, KPCs appeared a major public health concern. Bacterial isolates producing KPCs are able to hydrolyze a broad spectrum of $\beta$-lactams including the penicillins, cephalosporins, carbapenems and monobactam. They have the potential to spread rapidly in hospital environments to cause nosocomial infections with high mortality rates [21]. KPC-producing Enterobacteriaceae stains are increasingly spreading throughout China $[2,9,11,22]$. The dominant clone of KPC-producing $K$. pneumoniae in China is ST11, which is closely related to ST258 reported worldwide [23]. A rapid method confirming KPCs is significant to control this spread.

In 2009, the CLSI recommended MHT to screen for the production of carbapenemase in Enterobacteriaceae

Table 2 bla $a_{\mathrm{KPC}}$ Real-time-PCR results compared with the MHT.

\begin{tabular}{lll}
\hline $\begin{array}{lll}\text { bla }_{\text {KPC }} \text { Real- } \\
\text { time-PCR* }\end{array}$ & \multicolumn{2}{c}{ MHT } \\
\cline { 2 - 3 } & Positive & Negative \\
\hline Positive & 29 & 0 \\
Negative & 0 & 130 \\
\hline
\end{tabular}

: The percent sensitivity was $100 \%$, and the percent specificity was $100 \%$. Exact Sig. (2-tailed) $=1.000 ;$ McNemar test. 


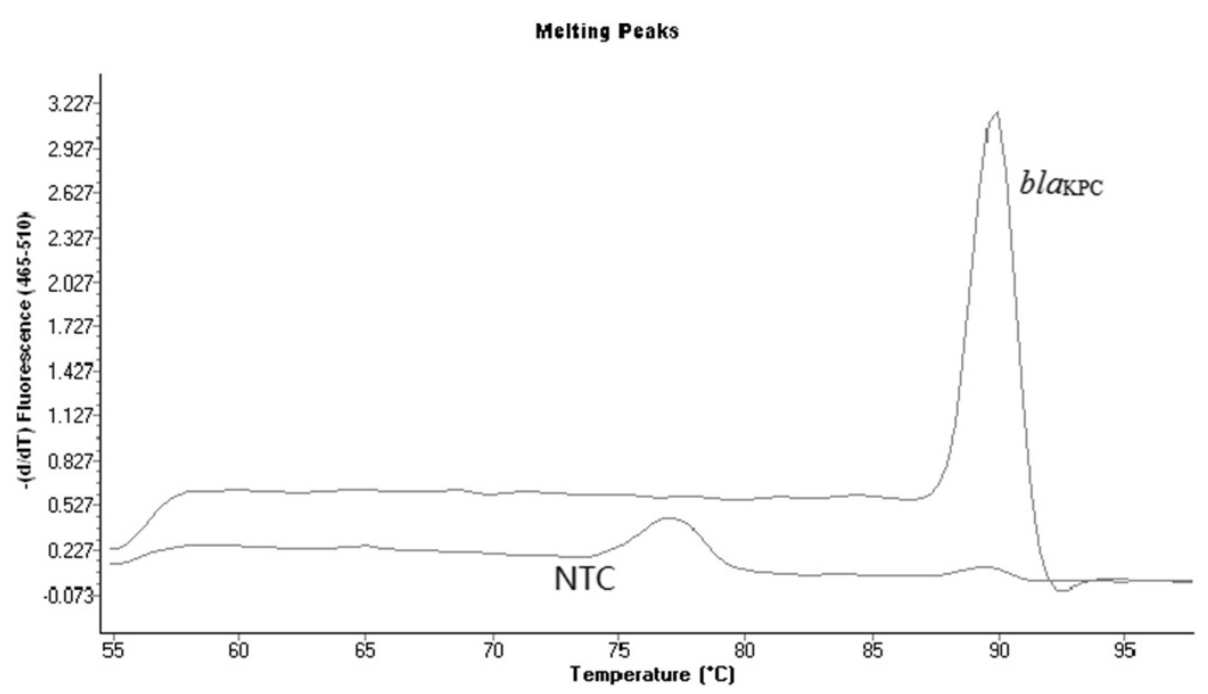

Figure 1 Plot of the negative derivative of the melting curves vs. temperature: peak indicates the $\mathrm{Tm}\left(\mathrm{about} 89^{\circ} \mathrm{C}\right)$ of isolates. NTC: no template control.

isolates with elevated MICs for carbapenems or reduced inhibition zones measured by disc diffusion. In 2010, Carbapenem breakpoints have changed in M100-S20U and M100-S21 with 2-fold lower MICs of each category (susceptible, intermediate, and resistant) for the Enterobacteriaceae for imipenem, meropenem, and ertapenem. According to the new criteria, the initial screen test and the confirmatory test by MHT are no longer necessary for routine patient testing. However, one isolate of E. coli with MIC to imipenem as low as $1 \mu \mathrm{g} / \mathrm{ml}$ was confirmed as MHT $(+) / b l a_{\mathrm{KPC}}(+)$ in our study. Decreased ertapenem susceptibility has been considered as one of the most sensitive phenotypic indicators of KPC production, but it has been found to be nonspecific [24,25]. In our laboratory, two clinical isolates MICs to ertapenem as high as $2 \mu \mathrm{g} / \mathrm{ml}$ to $8 \mu \mathrm{g} / \mathrm{ml}$ were MHT ( - ) / bla $a_{\mathrm{KPC}}(-)$. Despite CLSI new recommendations, our laboratory continued to confirm KPC using MHT or PCR.

The sensitivity and specificity of the MHT have been shown to exceed $90 \%$; however, several reports have noted false positive results occurred when the MHT was used to detect carbapenemase in ESBL-producing isolates [15,26]. In addition, it may not be the ideal phenotypic confirmatory test for KPCs since interpretation can be difficult for some isolates such as A. baumanii, $P$. aeruginasa. In our study, we adjusted the

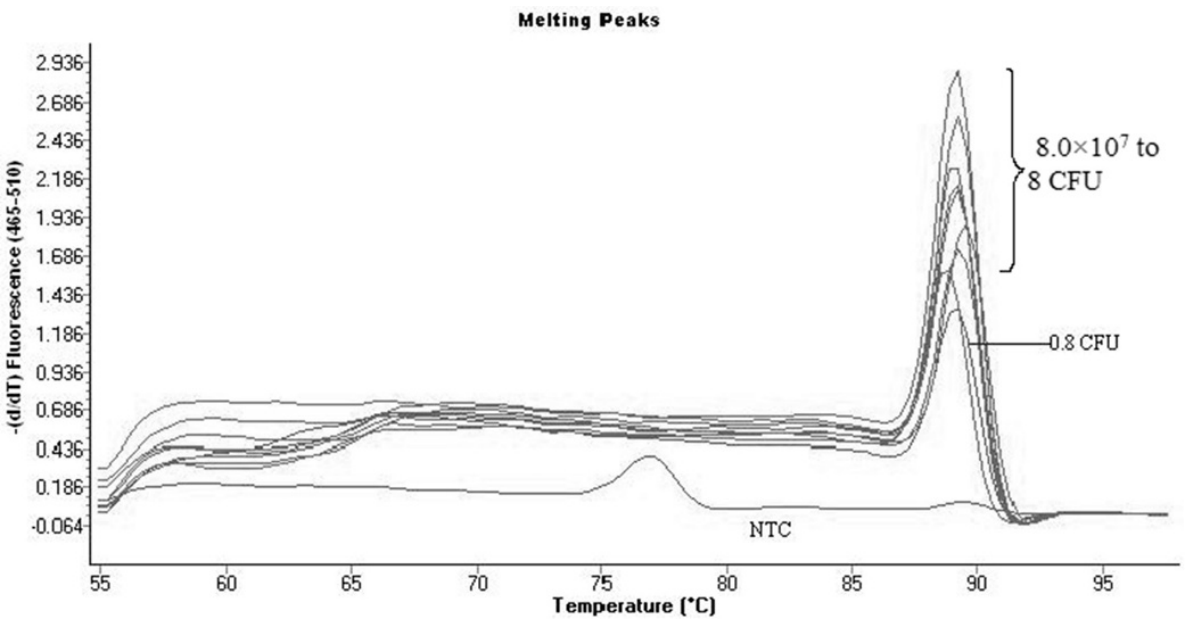

Figure 2 Analytical sensitivity of the bla $a_{\mathrm{KPC}}$ real-time-PCR assay showing a minimum detection limit of $0.8 \mathrm{CFU}$. 
indicator stain to K. pneumoniaeATCC 700603 for nonEnterobacteriaceae in order to eliminate the incidence of indeterminate results of MHT [20]. Thus, an alternative method may prove to be more useful. During the recent few years, molecular methods have been used to rapidly detect $b l a_{\mathrm{KPC}}$ genes. In particular, real-time PCR assays offered the advantage of shorter turnaround time, which were even developed to detect KPC-containing strains with high analytical specificity and sensitivity in surveillance specimens $[27,28]$.

In this study, we validated a rapid, sensitive, and specific real-time-PCR assay for the detection of $b l a_{\mathrm{KPC}}$ genes. This assay can be performed in less than 4 hours, which will reduce the chance of spreading the organism in the hospital. The real-time PCR assay specifity and sensitivity were $100 \%$ compared to phenotypic KPC activity assessed by MHT and sequencing. Thirteen KPC gene variants have been described, classified in sequential numeric order from $b l a_{\mathrm{KPC}-1 / 2}$ to $b l a_{\mathrm{KPC}-13}$. The $b l a_{\mathrm{KPC}}$ genes are characterized by nonsynonymous single nucleotide substitutions [17]. Our sequencing results showed all $29 \mathrm{KPC}$-producing isolates harbored $b l a_{\mathrm{KPC}-2}$ gene. KPC-2 clinical isolates were widely isolated in most parts of China [23,29]. Last year, Li et al [30] in China firstly described KPC-3-harboring E. coli and C. freundii. Although KPC-2 and KPC-3 were well described throughout China, we designed the primers in conservative areas to ensure that our assay could almost detect the variants currently described. We identified $b l a_{\mathrm{KPC}}$ genes by melting curve analysis of the amplification product using SYBR GreenIwith many advantages like low-cost and easy to use. The Tm value of the bla $a_{\mathrm{KPC}}$ gene was detected at about $89^{\circ} \mathrm{C}$. Our assay sensitivity is about one cfu sufficient to detect $b l a_{\mathrm{KPC}}-$ containing isolates.

\section{Conclusions}

The real-time PCR assay described here provides a useful screening test to detect $b l a_{\mathrm{KPC}}$ genes rapidly and accurately. Although the real-time PCR assay was unable to identify the specific gene in the $b l a_{\mathrm{KPC}}$ family in clinical isolates, accurate and rapid identification of this kind of resistance genes is the first step to control their spread.

\section{Abbreviations \\ KPC: Klebsiella pneumonia carbapenemase; MHT: modified Hodge test; CLSI: the Clinical Laboratory Standards Institute; cfu: colony forming unit; MIC: Minimum inhibitory concentration.}

\section{Competing interests}

The authors declare that they have no conflict of interest.

\section{Acknowledgements}

The National Science Foundation of China (No. 30970126) and Research Foundation of Beijing Tongue Hospital Affiliated to Capital Medical University (No. 2012-YJJ-010) financially supported this work.

\section{Authors' contributions}

$\llcorner J$ Wang carried out the real-time PCR studies, participated in the sequence alignment and drafted the manuscript. HT Gu carried out the bacterium isolation and antibiotic sensitivity test. XX Lu participated in the design of the study and coordination and helped to draft the manuscript. All authors read and approved the final manuscript.

Received: 28 February 2012 Accepted: 30 April 2012

Published: 30 April 2012

\section{References}

1. Yigit H, Queenan AM, Anderson GJ, Domenech-Sanchez A, Biddle JW, Steward CD, Alberti S, Bush K, Tenover FC: Novel carbapenem-hydrolyzing beta-lactamase, KPC-1, from a carbapenem-resistant strain of Klebsiella pneumoniae. Antimicrobial agents and chemotherapy 2001, 45:1151-1161.

2. Wei Z-Q, Du X-X, Yu Y-S, Shen P, Chen Y-G, Li L-J: Plasmid-Mediated KPC-2 in a Klebsiella pneumoniae Isolate from China. Antimicrobial agents and chemotherapy 2007, 51:763-765.

3. Villegas MV, Lolans K, Correa A, Suarez CJ, Lopez JA, Vallejo M, Quinn JP: First detection of the plasmid-mediated class A carbapenemase KPC-2 in clinical isolates of Klebsiella pneumoniae from South America. Antimicrobial agents and chemotherapy 2006, 50:2880-2882.

4. Leavitt A, Carmeli Y, Chmelnitsky I, Goren MG, Ofek I, Navon-Venezia S: Molecular epidemiology, sequence types, and plasmid analyses of KPCproducing Klebsiella pneumoniae strains in Israel. Antimicrobial agents and chemotherapy 2010, 54:3002-3006.

5. Cuzon G, Naas T, Demachy MC, Nordmann P: Plasmid-mediated carbapenem-hydrolyzing beta-lactamase KPC-2 in Klebsiella pneumoniae isolate from Greece. Antimicrobial agents and chemotherapy 2008, 52:796-797.

6. Robledo IE, Aquino EE, Santé MI, Santana JL, Otero DM, León CF, Vázquez GJ: Detection of KPC in Acinetobacter spp. in Puerto Rico. Antimicrobial agents and chemotherapy 2010, 54:1354-1357.

7. Yigit H, Queenan AM, Rasheed JK, Biddle JW, Domenech-Sanchez A, Albert S, Bush K, Tenover FC: Carbapenem-resistant strain of Klebsiella oxytoca harboring carbapenem-hydrolyzing beta-lactamase KPC-2. Antimicrobial agents and chemotherapy 2003, 47:3881-3889.

8. Gupta N, Limbago BM, Patel JB, Kallen AJ: Carbapenem-resistant Enterobacteriaceae: epidemiology and prevention. Clinical infectious diseases: an official publication of the Infectious Diseases Society of America 2011, 53:60-67.

9. Sheng ZK, Li JJ, Sheng GP, Sheng JF, Li LJ: Emergence of Klebsiella pneumoniae carbapenemase-producing Proteus mirabilis in Hangzhou, China. Chinese medical journal 2010, 123:2568-2570.

10. Villegas MV, Lolans K, Correa A, Kattan JN, Lopez JA, Quinn JP: First identification of Pseudomonas aeruginosa isolates producing a KPC-type carbapenem-hydrolyzing beta-lactamase. Antimicrobial agents and chemotherapy 2007, 51:1553-1555.

11. Cai JC, Zhou HW, Zhang R, Chen G-X: Emergence of Serratia marcescens, Klebsiella pneumoniae, and Escherichia coli Isolates Possessing the Plasmid-Mediated Carbapenem-Hydrolyzing $\beta$-Lactamase KPC-2 in Intensive Care Units of a Chinese Hospital. Antimicrobial agents and chemotherapy 2008, 52:2014-2018.

12. Doern CD, Dunne WM Jr: Burnham CA: Detection of Klebsiella pneumoniae carbapenemase (KPC) production in non-Klebsiella pneumoniae Enterobacteriaceae isolates by use of the Phoenix, Vitek 2, and disk diffusion methods. Journal of clinical microbiology 2011, 49:1143-1147.

13. Anderson KF, Lonsway DR, Rasheed JK, Biddle J, Jensen B, McDougal LK, Carey RB, Thompson A, Stocker S, Limbago B, Patel JB: Evaluation of methods to identify the Klebsiella pneumoniae carbapenemase in Enterobacteriaceae. Journal of clinical microbiology 2007, 45:2723-2725.

14. Tenover FC, Kalsi RK, Williams PP, Carey RB, Stocker S, Lonsway D, Rasheed JK, Biddle JW, McGowan JE Jr: Hanna B: Carbapenem resistance in Klebsiella pneumoniae not detected by automated susceptibility testing. Emerging infectious diseases 2006, 12:1209-1213.

15. Wang $P$, Chen $S$, Guo $Y$, Xiong Z, Hu F, Zhu D, Zhang Y: Occurrence of false positive results for the detection of carbapenemases in carbapenemasenegative Escherichia coli and Klebsiella pneumoniae isolates. PloS one 2011, 6:e26356.

16. Cole JM, Schuetz AN, Hill CE, Nolte FS: Development and evaluation of a real-time PCR assay for detection of Klebsiella pneumoniae carbapenemase genes. Journal of clinical microbiology 2009, 47:322-326.

17. Chen L, Mediavilla JR, Endimiani A, Rosenthal ME, Zhao Y, Bonomo RA, Kreiswirth BN: Multiplex real-time PCR assay for detection and 
classification of Klebsiella pneumoniae carbapenemase gene (bla KPC) variants. Journal of clinical microbiology 2011, 49:579-585.

18. Hindiyeh M, Smollan G, Grossman Z, Ram D, Robinov J, Belausov N, BenDavid D, Tal I, Davidson Y, Shamiss A, et al: Rapid detection of blaKPC carbapenemase genes by internally controlled real-time PCR assay using bactec blood culture bottles. Journal of clinical microbiology 2011, 49:2480-2484

19. Raghunathan A, Samuel L, Tibbetts RJ: Evaluation of a real-time PCR assay for the detection of the Klebsiella pneumoniae carbapenemase genes in microbiological samples in comparison with the modified Hodge test. American journal of clinical pathology 2011, 135:566-571.

20. Pasteran F, Veliz O, Rapoport M, Guerriero L, Corso A: Sensitive and Specific Modified Hodge Test for KPC and Metallo-Beta- Lactamase Detection in Pseudomonas aeruginosa by Use of a Novel Indicator Strain, Klebsiella pneumoniae ATCC 700603. Journal of clinical microbiology 2011, 49:4301-4303.

21. Hirsch EB, Tam VH: Detection and treatment options for Klebsiella pneumoniae carbapenemases (KPCs): an emerging cause of multidrugresistant infection. The Journal of antimicrobial chemotherapy 2010, 65:1119-1125.

22. Zhang R, Wang XD, Cai JC, Zhou HW, Lv HX, Hu QF, Chen GX: Outbreak of Klebsiella pneumoniae carbapenemase 2-producing K. pneumoniae with high qnr prevalence in a Chinese hospital. Journal of medical microbiology 2011, 60:977-982.

23. Qi Y, Wei Z, Ji S, Du X, Shen P, Yu Y: ST11, the dominant clone of KPCproducing Klebsiella pneumoniae in China. The Journal of antimicrobial chemotherapy 2011, 66:307-312

24. Gomez E, Urban C, Mariano N, Colon-Urban R, Eng RH, Huang DB, Chiang T: Phenotypic and genotypic screening and clonal analysis of carbapenemresistant Klebsiella pneumoniae at a single hospital. Microbial drug resistance (Larchmont, NY) 2011, 17:251-257.

25. Lolans K, Calvert K, Won S, Clark J, Hayden MK: Direct ertapenem disk screening method for identification of KPC-producing Klebsiella pneumoniae and Escherichia coli in surveillance swab specimens. Journal of clinical microbiology 2010, 48:836-841.

26. Carvalhaes CG, Picao RC, Nicoletti AG, Xavier DE, Gales AC: Cloverleaf test (modified Hodge test) for detecting carbapenemase production in Klebsiella pneumoniae: be aware of false positive results. The Journal of antimicrobial chemotherapy 2010, 65:249-251.

27. Mangold KA, Santiano K, Broekman R, Krafft CA, Voss B, Wang V, Hacek DM Usacheva EA, Thomson RB Jr, Kaul KL, Peterson LR: Real-time detection of blaKPC in clinical samples and surveillance specimens. Journal of clinical microbiology 2011, 49:3338-3339.

28. Schechner V, Straus-Robinson K, Schwartz D, Pfeffer I, Tarabeia J, Moskovich R, Chmelnitsky I, Schwaber MJ, Carmeli Y, Navon-Venezia S: Evaluation of PCR-based testing for surveillance of KPC-producing carbapenemresistant members of the Enterobacteriaceae family. Journal of clinical microbiology 2009, 47:3261-3265.

29. Shen P, Wei Z, Jiang Y, Du X, Ji S, Yu Y, Li L: Novel Genetic Environment of the Carbapenem-Hydrolyzing $\beta$-Lactamase KPC-2 among Enterobacteriaceae in China. Antimicrobial agents and chemotherapy 2009, 53:4333-4338.

30. Li G, Wei Q, Wang Y, Du X, Zhao Y, Jiang X: Novel genetic environment of the plasmid-mediated KPC-3 gene detected in Escherichia coli and Citrobacter freundii isolates from China. European journal of clinical microbiology \& infectious diseases: official publication of the European Society of Clinical Microbiology 2011, 30:575-580

doi:10.1186/1476-0711-11-9

Cite this article as: Wang et al: A rapid low-cost real-time PCR for the detection of klebsiella pneumonia carbapenemase genes. Annals of Clinical Microbiology and Antimicrobials 2012 11:9. 